\title{
Dampak Kelelehan Terhadap Pengambilan Keputusan di Dalam Permainan Futsal
}

\author{
Radyan Ferdiansyah, Iman Imanuddin, Mustika Fitri \\ Universitas Pendidikan Indonesia, Indonesia \\ Diterima: 17 February 2020. Direvisi: 31 Agustus 2020. Disetujui: 6 November 2020
}

\begin{abstract}
Abstrak Intensitas yang tinggi pada olahraga futsal mengakibatkan para pemainnya sering mengalami kelelahan sebelum pertandingan selesai. Pada akhirnya, kelelahan akan menyebabkan penurunan performa. Oleh karna itu peneliti ingin melakukan penelitian ini untuk mengetahui tentang dampak kelelahan terhadap pengambilan keputusan di dalam permainan futsal. Tujuan penelitian ini untuk mengetahui pengambilan keputusan atlet yang sedang mengalami kelelahan dan tidak. Setelah mengetahui, maka peneliti mencari perbedaan pengambilan keputusan antara kelompok yang mengalami kelelahan dan tidak mengalami kelelahan. Pada penelitian ini menggunakan metode dengan pendekatan kuantitatif dengan desain kausal komparatif. Partisipan pada penelian ini adalah Siswa Sekolah Menengah Pertama PGII II Bandung yang terdaftar aktif di ekstrakulikuler futsal. Sampel pada penelitian ini berjumlah 16 orang yang dipilih menggunakan teknik sampling porposive sampling, instrumen penelitian pada penelitian ini menggunakan Assessment of Secondary School Student's Decision Making and Gameplay Ability in Soccer. Berdasarkan hasil pengolahan data dan analisis data uji perbedaan sebelum dan sesudah kelelahan maka diperoleh data signifikansi sebesar 0,022 maka H0 ditolak. Sehingga dapat disimpulkan bahwa ada perbedaan pengambilan keputusan sebelum dan selama kelelahan. Dengan demikian, karena nilai t hitung 2,409 > t, tabel 1,6973 maka dapat disimpulkan bahwa H0 ditolak dan Ha diterima. Artinya kelelahan berdampak terhadap pengambilan keputusan di dalam permainan futsal.
\end{abstract}

Keywords: Futsal; Kelelahan; Pengambilan Keputusan

\section{PENDAHULUAN}

Intensitas yang tinggi pada olahraga futsal juga mengakibatkan para pemainnya sering mengalami kelelahan sebelum pertandingan selesai (Royal et al., 2006). Pada saat pertandingan, seorang pemain dapat mengalami penurunan performance yang diakibatkan oleh kelelahan (Halson, 2014). Pada olahraga, kelelahan ini diakibatkan oleh banyak faktor antara lain intensitas, durasi hingga menyebabkan kurangnya energi dalam aktifitas dan adanya penumpukan asam laktat hasil sisa metabolisme (Smits, Pepping, \& Hettinga, 2014).
Research menunjukan kelelahan dapat mengganggu konsentrasi, kemampuan persepsi, dan pengambilan keputusan yang buruk di dalam sebuah permainan, walaupun kerancuan akibat pengaruh faktor lain bisa saja terjadi (multi-faktorial) (Martin, Thompson, Keegan, Ball, \& Rattray, 2015)however, unclear. Therefore, the aim of the present study was to induce a state of mental fatigue to examine the effects on performance, physiological and perceptual variables from subsequent tests of power, strength and anaerobic capacity. Methods: Twelve participants took part in the single-blind, randomised, crossover design study. Mental fatigue was induced by $90 \mathrm{~min}$ of the computerbased Continuous Performance Task AX version. Control treatment consisted of $90 \mathrm{~min}$ of watching emotionally neutral documentaries. Participants consequently completed countermovement jump, isometric leg extension and a 3-min all-out cycling tests. Results: Results of repeated measures analysis of variance and paired $t$ tests revealed no difference in any performance or physiological variable. Rating of perceived exertion tended to be greater when mentally fatigued (mental fatigue $=19 \pm 1$ vs control $=18 \pm 1, p=0.096$, (Formula presented. . Kelelahan fisik menyebabkan memburuknya kecepatan dalam pengambilan keputusan di dalam pertandingan simulasi (Rampinini, Impellizzeri, Castagna, Coutts, \& Wisløff, 2009).

Kelelahan dan pengambilan keputusan adalah salah satu yang belum terselesaikan, meskipun banyak penelitian telah menunjukan bahwa kelelahan berdampak terhadap kinerja menendang pemain sepak bola (misalnya, (R. M. P. Ferraz, van den Tillaar, Pereira, \& Marques, 2016) dan kecepatan menendang pemain sepak bola (R. Ferraz, Van Den Tillaar, \& Marques, 2012) menunjukkan bahwa sebagian be- 
sar penelitian dilakukan dengan cara melihat dampak dari kelelahan. Oleh karena itu kelelahan dan pengambilan keputusan ini meskipun masuk akal, tetap belum meyakinkan

\section{METODE}

Desain Penelitian yang digunakan yaitu kausal komparatif. Peneliti membagi sample menjadi dua kelompok yang dilihat dari hasil RAST Test, kelompok pertama yaitu kelompok yang mengalami kelelahan dan kelompok kedua yaitu kelompok yang tidak mengalami kelelahan. Berkaitan dengan penelitian komparatif, penulis mengacu pada pendapat yang dikemukakan oleh (Jack R. Fraenkel, 2012)

Sampel yang digunakan adalah siswa sekolah menengah pertama PGII II Bandung yang aktif di ekstrakulikuler futsal berjumlah 16 orang. Teknik sampel yang digunakan dalam penelitian ini adalah dengan teknik purposive sampling yaitu teknik dengan pemilihan sampel yang terdiri dari individu yang memiliki kualifikasi khusus (Fraenkel, Wallen, \& Hyun, 2015). Selain itu ada pula kriteria dari penelitian ini adalah siswa PGII II Bandung aktif ekstrakulikuler futsal dengan umur 14-15 tahun.

Penelitian ini menggunakan 2 jenis instrumen untuk melihat indeks kelelahan dan untuk menilai pengambilan keputusan. Test yang pertama adalah Running-based Anaerobic Sprint Test (RAST) (Mackenzie, 2005)and is thus objective rather than subjective. In doing so all tests should therefore be specific (designed to assess an athlete's fitness for the activity in question, dan yang terakhir tes keterampilan bermain dengan menggunakan Assessment of Secondary School Student's Decision Making and Gameplay Ability in Soccer (Blomqvist, Vänttinen, \& Luhtanen, 2005).

Prosedur penelitian ini pertama menentukan sampel dari populasi yang ada dengan menggunakan teknik purposive sampling. Lalu melakukan test pertama dengan melakukan RAST Test untuk mengetahui indeks kelelahan dan membagi dua kelompok yaitu: kelompok yang lelah dan tidak lelah. Test kedua yang dilakukan adalah melakukan dua kali game simulasi untuk mengetahui pengambilan keputusan dengan baik, peneliti menilai menggunakan Assessment of Secondary School Student's Decision Making and Gameplay Ability in Soccer dengan dua kelompok sampel sedang berada tidak lelah dan sedang mengalami kelelahan. Data yang diperoleh diolah menggu- nakan SPSS (Statistic Package for Sosial Science) seri 25. Menyimpulkan hasil analisis data.

Penelitian ini menggunakan analisis Independent sampel T-test. Pada penelitian ini melihat dari hasil perbedaan apakah kelelehan berdampak pada pengambilan keputusan di dalam permainan futsal. Analisis data ini dibantu menggunakan sebuah software yaitu Statistikal Package for Social Science (SPSS) versi 25.

\section{HASIL DAN PEMBAHASAN}

Metode dalam penelitian ini menggunakan desain penelitian komparatif yaitu dengan membandingkan keberadaan satu variabel atau lebih pada dua atau lebih sampel yang berbeda, atau pada waktu yang berbeda (Sugiyono, 2006). Setelah itu dibagi ke dalam dua kelompok kemudian data dihitung, hasil data deskriftif adalah sebagai berikut :

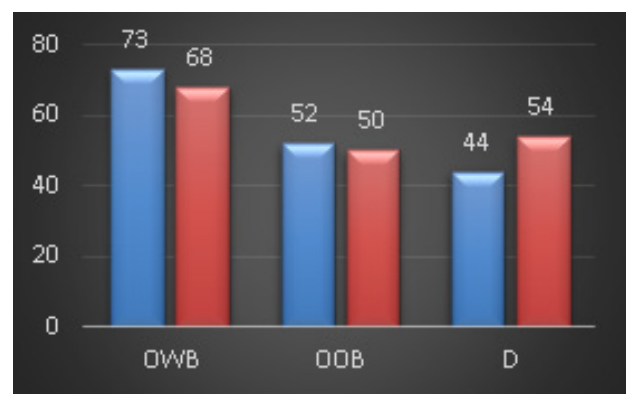

Keterangan: Biru: Kelompok yang tidak lelah; Merah: Kelompok lelah OWB : Offence With the Ball; OOB : Offence Off the Ball; D : Defence

Dari data dapat dideskripsikan yaitu: sebelum kelelahan sampel melakukan Offence With the Ball sebanyak 73 kali, saat selama kelelahan melakukan Offence With the Ball sebanyak 68 kali. Selanjutnya, selama kelelahan melakukan Offence Off the Ball sebanyak 52 kali, saat selama kelelahan melakukan Offence Off the Ball sebanyak 50 kali. Selanjutnya, sebelum kelelahan melakukan Defence sebanyak 44 kali, saat selama kelelahan melakukan Defence sebanyak 54 kali

Berdasarkan hasil penghitungan statistik dengan sofware SPSS (Statistic Package for Sosial Science) seri 25 dengan menggunakan uji Shapiro-Wilk dapat diketahui bahwa data sebelum kelelahan offence with the ball, offence off the ball dan defence dengan nilai sig. lebih besar dari taraf nyata (a) 0,05 artinya $\mathrm{H}_{0}$ diterima maka data berdistribusi normal.

Berdasarkan hasil penghitungan statistik dengan sofware SPSS (Statistic Package for Sosial Science) seri 25 dengan menggunakan uji Shapi- 
ro-Wilk dapat diketahui bahwa data selama kelelahan berdasarkan offence with the ball, offence off the ball dan defence dengan nilai sig. lebih besar dari taraf nyata (a) $0,05 \mathrm{H}_{0}$ diterima maka artinya data berdistribusi normal.

Berdasarkan hasil penghitungan statistik dengan sofware SPSS (Statistic Package for Sosial Science) seri 25 dengan menggunakan uji Lavene Statistic dapat diketahui bahwa data sebelum dan setelah kelelahan berdasarkan Offence with the ball, Offence off the ball dan Defence dengan nilai sig. lebih besar dari taraf nyata (a) $0,05 \mathrm{H}_{0}$ diterima maka artinya data berdistribusi homogen.

Dari uji beda sebelum dan selama kelelahan maka diperoleh data signifikansi sebesar 0,022 maka $\mathrm{H}_{0}$ ditolak, menunjukkan bahwa secara statistik terdapat perbedaan pengambilan keputusan sebelum dan selama kelelahan dalam permainan futsal. Dengan demikian, karena nilai t hitung 2,409 > t, tabel 1,6973 maka dapat disimpulkan bahwa H0 ditolak dan Ha diterima. Sehingga dapat disimpulkan bahwa ada perbedaan pengambilan keputusan sebelum dan selama kelelahan yang artinya kelelahan berdampak terhadap pengambilan keputusan di dalam permainan futsal. $\mathrm{T}$ hitung bernilai positif disebabkan nilai rata pengambilan keputusan sebelum kelelahan lebih tinggi dari nilai rata rata pengambilan keputusan selama kelelahan.

\section{SIMPULAN}

Setelah mendapatkan hasil dari penelitian dilanjutkan dengan pembahasan terkait masalah yang sedang diteliti. Dimana tujuan dari penelitian ini yaitu untuk mengetahui perbedaan pengambilan keputusan sebelum dan selama dalam permainan futsal. Nilai ratarata pada pengambilan keputusan selama kelelahan mengalami penurunan dari sebelum kelelahan. Hal ini dikarenakan pada saat mengalami kelelahan maka kemampuan seseorang untuk melakukan aktifitas mengalami penurunan. Seperti yang dikemukakan oleh (Oesman \& Simanjuntak, 2011) bahwa "kelelahan dapat didefinisikan sebagai penurunan kinerja dalam melanjutkan aktifitas. Selain itu, Menurut (Barte, Nieuwenhuys, Geurts, \& Kompier, 2017)“ In sports, fatigue may be even more prominent due to prolonged and/or repeated high-intensity activity...". Hal ini dapat diartikan bahwa dalam olahraga, kelelahan mungkin lebih menonjol karena aktifitas-aktifitas yang kita lakukan dilakukan secara berulang dengan intensitas yang tinggi. Hal ini menunjukkan terdapat perbedaan pengambilan keputusan sebelum dan selama kelelahan di dalam permainan futsal.

\section{DAFTAR PUSTAKA}

Blomqvist, M., Vänttinen, T., \& Luhtanen, P. (2005). Assessment of secondary school students' decisionmaking and game-play ability in soccer. Physical Education \& Sport Pedagogy, 10(2), 107-119. https:/ / doi.org/10.1080/17408980500104992

Ferraz, R. M. P., van den Tillaar, R., Pereira, A., \& Marques, M. C. (2016). The effect of fatigue and duration knowledge of exercise on kicking performance in soccer players. Journal of Sport and Health Science. https:// doi.org/10.1016/j.jshs.2016.02.001

Ferraz, R., Van Den Tillaar, R., \& Marques, M. C. (2012). The effect of fatigue on kicking velocity in soccer players. Journal of Human Kinetics. https://doi. org/10.2478/v10078-012-0083-8

Fraenkel, J. R., Wallen, N. E., \& Hyun, H. H. (2015). The nature of research. How to Design and Evaluate Research in Education, 1-26.

Halson, S. L. (2014). Monitoring Training Load to Understand Fatigue in Athletes. Sports Medicine, 44, 139147. https:/ / doi.org/10.1007/s40279-014-0253-z

Jack R. Fraenkel, N. E. W. (2012). how-to-design-and-evaluate-research-in-education.

Mackenzie, B. (2005). 101 Performance Evaluation Test.

Martin, K., Thompson, K. G., Keegan, R., Ball, N., \& Rattray, B. (2015). Mental fatigue does not affect maximal anaerobic exercise performance. European Journal of Applied Physiology, 115(4), 715-725. https:/ / doi.org/10.1007/s00421-014-3052-1

Rampinini, E., Impellizzeri, F. M., Castagna, C., Coutts, A. J., \& Wisløff, U. (2009). Technical performance during soccer matches of the Italian Serie A league: Effect of fatigue and competitive level. Journal of Science and Medicine in Sport, 12(1), 227-233. https:/ / doi.org/10.1016/j.jsams.2007.10.002

Royal, K. A., Farrow, D., Mujika, I., Halson, S. L., Pyne, D., \& Abernethy, B. (2006). The effects of fatigue on decision making and shooting skill performance in water polo players. Journal of Sports Sciences, 24(8), 807-815. https://doi. org/10.1080/02640410500188928

Smits, B. L. M., Pepping, G. J., \& Hettinga, F. J. (2014). Pacing and decision making in sport and exercise: The roles of perception and action in the regulation of exercise intensity. Sports Medicine, 44(6), 763-775. https:/ / doi.org/10.1007/s40279-014-0163-0 